\title{
PENILAIAN BERBASIS KELAS UNTUK MENINGKATKAN PRESTASI BELAJAR PADA MATERI PERSILANGAN
}

\author{
Nurhidayah \\ SMP Negeri 131 Jakarta \\ Email: idabarus70@gmail.com
}

\begin{abstract}
Abstrak
Penelitian ini bertujuan untuk meningkatkan penguasaan konsep persilangan melalui metode penilaian berbasis kelas di SMP Negeri 131 Jakarta. Pelaksanaan tindakan kelas dilakukan dengan 2 Siklus (I dan II) bulan Juli sampai dengan Oktober 2019 dengan tahapan perencanaan, pelaksanaan dan refleksi. Analisis data dan pembahasan dilakukan dengan teknik kuantitatif dan kualitatif sederhana dengan melihat peningkatan tiap siklus. Untuk mengukur peningkatan kemampuan digunakan instrumen berupa LKPD dan tes tulis berbentuk pilihan ganda. Untuk mengukur perubahan sikap saat berlangsung proses pembelajaran digunakan wawancara dan lembar observasi. Hasil penelitian menunjukkan adanya peningkatan kompetensi penguasaan peserta didik terhadap konsep persilangan yang awalnya di bawah KKM (80), dan cenderung terus meningkat dari 80,83 hingga 86,11. Pada aspek sikap terdapat arah yang positif dalam menerima pembelajaran, situasi kelas cukup aktif dan partisipatif. Akhirnya dapat disimpulkan bahwa metode penilaian berbasis kelas cukup efektif meningkatkan kompetensi peserta didik pada konsep persilangan, dan efektif untuk meningkatkan sikap dalam mengikuti proses pembelajaran. Implikasi hasil penelitian adalah mengenai sikap positif, situasi kelas dalam pembelajaran mempunyai hubungan dengan kemampuan mengajar guru, sehingga guru menjadi semakin tertantang meningkatkan kemampuan mengajar secara inovatif. Hasil penelitian ini juga menjadi rujukan bagi kolega sejawat dalam mengembangkan pembelajaran berbasis kelas.
\end{abstract}

Kata Kunci : Penilaian Berbasis Kelas, Persilangan Pewarisan Sifat, Prestasi Belajar

\begin{abstract}
This study aims at improving the understanding of crossbreeding concepts through class-based assessment methods at SMP Negeri 131 Jakarta. Classroom action research was conducted in 2 cycles (I and II) from July to October 2019 with stages of planning, implementation and reflection. Data analysis and discussion were carried out using quantitative and qualitative techniques by observing the improvement in each cycle. The ability measuring instruments were LKPD and multiple choice written tests. The attitude measuring instruments during the learning process were interviews and observation sheets. The result showed an increase in competence of students' understanding in crossbreeding concept which was initially under the KKM (80), and tended to increase from 80.83 to 86.11. In the attitude aspect, there was a positive response in accepting learning, the classroom was quite active and participatory. It can be concluded that the class-based assessment method is effective in increasing the understanding of students in crossbreeding concepts, as well as improving students' attitudes during the learning process. The implication of this study is the positive attitude, classroom situation is related with the teachers' teaching ability so teachers become challenged to improve. This study is also a reference for colleagues in developing class-based learning.
\end{abstract}

Key Words : Learning achievement, Inheritance crossbreeding, Class Based Assessment

\section{PENDAHULUAN}

Upaya meningkatkan hasil belajar para peserta didik di setiap jenjang dan tingkat pendidikan diwujudkan agar kualitas sumber daya manusia dapat menunjang pembangunan nasional. Penguasaan materi IPA kelas IX SMP Negeri 131 Jakarta pada materi persilangan tahun 2019 untuk menunjang upaya tersebut masih rendah
$(\mathrm{KKM}<80)$. Pemilihan metode dan strategi telah diupayakan [1] dalam mengajar pada setiap topik. Materi persilangan yang cukup banyak memang tidak sebanding dengan waktu yang tersedia. Prestasi belajar peserta didik materi persilangan menjadi perhatian serius pada penelitian ini bagi guru mata pelajaran IPA. 
Menurut [2] dan [3], beberapa aspek kelemahan yang ditimbulkan dari model mengajar guru yang telah diuraikan di atas antara lain karena peserta didik: (1) kurang melibatkan mental dalam proses belajar mengajar; (2) kurang mendapat kesempatan untuk berpikir sendiri, melakukan eksperimen; dan (3) cenderung pasif sehingga guru tidak banyak mendapat umpan balik. Kondisi peserta didik sebagai objek penelitian ini terlihat cukup lamban dalam menerima materi pelajaran yang diberikan khususnya materi persilangan. Selanjutnya, penelitian ini berupaya mengungkapkan hasil pembelajaran materi persilangan dalam pelajaran IPA. Peningkatan prestasi belajar harus dilaksanakan secara terpadu termasuk usaha penerapan metode Penilaian Berbasis Kelas (PBK). Penilaian berbasis kelas sebagai "assessmen" yaitu kegiatan yang dilakukan untuk memperoleh dan mengefektifkan informasi tentang hasil belajar peserta didik pada tingkat kelas selama dan setelah kegiatan belajar mengajar [4].

Penilaian Berbasis Kelas (PBK) merupakan salah satu metode evaluasi pengajaran yang diharapkan mampu meningkatkan kompetensi peserta didik yang lebih baik [5]. Kajian penelitian tindakan kelas ini adalah "Peningkatan Prestasi Belajar Materi Persilangan (IPA) Peserta didik Melalui Metode Penilaian Berbasis Kelas". Teknik penilaian berbasis kelas dilakukan dengan berbagai cara, seperti pengumpulan karya peserta didik (portofolio), hasil karya (produk), penugasan (proyek), kinerja (performance), dan tes tertulis (paper and pencil). Guru akan menilai kompetensi dan hasil belajar peserta didik berdasarkan level pencapaian KKM. Penelitian ini bertujuan untuk menggunakan metode dan prosedur tindakan yang tepat untuk memberikan jaminan terhadap upaya meningkatkan prestasi belajar IPA peserta didik melalui penilaian berbasis kelas.

Bentuk penilaian yang akhir-akhir ini sering diperbincangkan adalah Penilaian Berbasis Kelas (PBK) yang merupakan bagian terpadu dari kegiatan belajar mengajar (KBM) secara keseluruhan. Keberhasilan dan efektivitas KBM bergantung kepada efektivitas penilaian kelas yang dilakukan [6]. Oleh karena itu, kegiatan penilaian kelas harus didesain dan dilakukan secara sistematik dan terus menerus sebagai strategi untuk mendukung dan meningkatkan mutu KBM.

Tes merupakan teknik penilaian yang paling banyak dilakukan guru di dalam penilaian kelas. Selain itu, kebanyakan tes yang buat guru menggunakan kombinasi soal uraian dan pilihan ganda [7]. Mutu soal dan tujuan pembelajaran yang dibuat guru juga bervariasi antar guru dan antar sekolah. Banyak tujuan pembelajaran yang dibuat guru terbatas kepada kemampuan sederhana atau tingkat rendah (seperti mengingat informasi).

Prestasi adalah hasil yang telah dicapai, dilakukan, dikerjakan, dan sebagainya (Kamus Besar IPA). Prestasi adalah "bukti usaha yang dapat dicapai" [8]. Berdasarkan pendapat di atas, dapat disimpulkan bahwa prestasi adalah hasil kegiatan nyata yang berupa kemampuan, kecakapan atau nilai. Sementara itu, belajar adalah suatu usaha menguasai hal-hal yang baru karena dalam belajar itu ada perubahan dalam diri seseorang sebagai suatu proses mengarah kepada perubahan pemahaman, sikap dan keterampilan [9]. Meniriy berpendapat bahwa belajar merupakan suatu proses yang ditandai dengan adanya perubahan pada diri peserta didik, berupa sikap maupun tingkah laku seseorang akan terbentuk, dimodifikasi dan berkembang menjadi sebuah prestasi belajar [10]. Belajar merupakan suatu proses yang 
ditandai dengan adanya perubahan tingkah laku pada diri seseorang. Belajar segala sesuatu yang ditandai dengan adanya perubahan pada diri seseorang [11]. Berdasarkan beberapa definisi tentang belajar maka disimpulkan bahwa belajar merupakan suatu proses perubahan perilaku, sebagai akibat interaksi individu dengan lingkungannya. Hasil merupakan sesuatu yang diperoleh dari suatu kegiatan yang telah dikerjakan atau diciptakan, baik secara individual maupun kelompok [12]. Hasil tersebut tidak akan pernah diperoleh selama seseorang tidak melakukan suatu kegiatan.

Persilangan adalah materi IPA yang membahas tentang mekanisme pewarisan sifat yang diturunkan kepada keturunannya (anaknya). Faktor pembawa sifat individu adalah kromosom yang terdiri dari satuansatuan kecil yaitu gen berperan mengatur sifat diwariskan pada keturunan selanjutnya. Materi persilangan konsepkonsep abstrak dalam materi ini disajikan dalam bentuk kongkrit menggunakan alat peraga ([2], [13]). Keberhasilan belajar peserta didik mata pelajaran IPA sangat ditentukan minat dan tingkat motivasinya. Melalui penerapan pendekatan penilaian berbasis kelas diharapkan dapat menimbulkan dampak positif bagi peningkatan mutu proses KBM, daya serap dan ketuntasan belajar IPA. Sesuai pernyataan bahwa "motivasi merupakan suatu proses psikologis yang mencerminkan interaksi antara sikap, kebutuhan, persepsi, dan keputusan yang terjadi pada diri seseorang" [14]. Motivasi sebagai proses psikologis timbul diakibatkan oleh faktor di dalam diri seseorang itu sendiri yang disebut intrinsik atau faktor diluar diri yang disebut faktor ekstrinsik.

\section{METODE}

Penelitian ini terdiri dari siklus I dan siklus II. Setiap siklus dilakukan dalam 3 tahapan utama, yaitu perencanaan, pelaksanaan, tindakan dan refleksi. Pada tahap siklus II bedanya merupakan revisi dari siklus I. Penerapan Metode Penilaian Berbasis Kelas dilakukan dengan berbagai cara, seperti pengumpulan karya peserta didik (portofolio), hasil karya peserta didik, penugasan, kinerja, dan tes tertulis. Penelitian dilakukan pada peserta didik kelas IX SMP Negeri 131 Jakarta, pada semester ganjil yaitu bulan Juli sampai September 2019. Penelitian tindakan kelas dikhususkan pada materi pewarisan sifat/persilangan (monohibrid dan dihibrid). Pembelajaran yang semula hanya ceramah saja, pada penelitian ini saya gunakan diskusi dan juga praktikum dengan menggunakan kancing genetika dilengkapi dengan (lembar kerja peserta didik) LKPD.

Teknik pengumpulan data yang akan digunakan adalah: a). Lembar observasi, berupa pengamatan terhadap proses pembelajaran; b). Wawancara, digunakan setelah kegiatan observasi dilaksanakan; c). Alat penilaian berbasis kelas seperti portofolio, hasil karya, penugasan, kinerja (LKPD), dan tes tertulis berupa soal pilihan ganda.

\section{HASIL DAN PEMBAHASAN}

Tindakan kelas yang dilakukan pada kelas IX mata pelajaran IPA, pada Kompetensi Dasar 3.3. Mengidentifikasi proses dan hasil pewarisan sifat serta penerapannya dalam pemuliaan mahluk hidup, berdasarkan hasil pengamatan pada siklus I dan siklus II, melalui metode Penilaian Berbasis Kelas suatu langkah pengumpulan informasi tentang pencapaian hasil belajar siswa serta pembuatan keputusan tentang hasil belajar siswa [5], dilakukan pembelajaran yang direncanakan secara baik sesuai dengan tahapan tindakan kelas, dengan tujuan peserta didik lebih kreatif dan semangat dalam mengikuti pembelajaran IPA. Tiap 
siklus menunjukkan ada perubahan peningkatan baik aktivitas dan hasil belajar. Hal ini ditunjukkan pada akhir tindakan peserta didik yang mencapai KKM dari jumlah 27 (siklus I) menjadi 34 peserta didik (siklus II). Selain peningkatan ketuntasan belajar penerapan metode penilaian berbasis kelas tersebut juga memberikan perubahan sebagai berikut.

1). Perubahan aktivitas peserta didik yang relevan diamati menggunakan lembar observasi diperoleh hasil yang tersaji pada Tabel 1.

\begin{tabular}{lcc}
\multicolumn{1}{c}{ Tabel 1 Peningkatan Aktivitas Peserta } \\
\multicolumn{1}{c}{ Didik yang Relevan } \\
\hline \multicolumn{1}{c}{ Indikator } & \multicolumn{2}{c}{ Keadaan } \\
\cline { 2 - 3 } & Siklus I & Siklus II \\
\hline $\begin{array}{l}\text { Memperhatikan } \\
\text { dengan seksama } \\
\text { penjelasan guru }\end{array}$ & 36 \\
Mempersiapkan diri & & \\
secara baik untuk \\
aktivitas \\
pembelajaran \\
Berinteraksi dengan \\
teman kelompok \\
dalam relevansinya \\
kegiatan \\
pembelajaran \\
$\begin{array}{l}\text { Aktif mencari } \\
\text { jawaban atau mencari } \\
\text { bahan-bahan untuk } \\
\text { ide dan } \\
\text { mendiskusikannya } \\
\text { dengan teman } \\
\text { kelompoknya }\end{array}$ \\
$\begin{array}{l}\text { Aktif menanyakan } \\
\text { materi pembelajaran }\end{array}$ \\
$\begin{array}{l}\text { IPA } \\
\text { Rata -Rata }\end{array}$ \\
\hline
\end{tabular}

Rata-rata peningkatan satu point pada perhatian peserta didik pada penjelasan guru, aktifitas pembelajaran, interaksi dengan teman kelompok, keaktifan mencari bahan untuk ide, dan keaktifan bertanya pada materi pelajaran.

2). Perubahan aktivitas KBM peserta didik [15] dengan LKPD yang diamati melalui lembar observasi diperoleh yang terlihat pada Tabel 2.

\begin{tabular}{|c|c|c|}
\hline \multirow{2}{*}{ Indikator } & \multicolumn{2}{|c|}{ Keadaan } \\
\hline & Siklus I & Siklus II \\
\hline Mengamati (M1) & 79,64 & 83,06 \\
\hline Menanya (M2) & 80,47 & 82,36 \\
\hline $\begin{array}{l}\text { Mengumpulkan } \\
\text { data/informasi (M3) }\end{array}$ & 80,17 & 82,44 \\
\hline $\begin{array}{l}\text { Menalar/Mengasosiasi } \\
\text { (M4) }\end{array}$ & 80,44 & 82,72 \\
\hline $\begin{array}{l}\text { Mengkomunikasikan } \\
\text { (M5) }\end{array}$ & 80,81 & 83,08 \\
\hline Rata-rata & 80,306 & 82,732 \\
\hline
\end{tabular}

Rata-rata peningkatan aktivitas KBM dengan LKPD sebesar 2,246\%. Proses pembelajaran dapat meningkatkan dalam hal kemampuan mengamati, menanya, mengumpulkan data/ informasi, menalar/ mengasosiasi, dan mengkomunikasikan.

3). Perubahan peningkatan aktivitas diskusi peserta didik yang diamati melalui lembar observasi diperoleh, terlihat pada Tabel 3.

Tabel 3. Peningkatan Aktivitas Diksusi

\begin{tabular}{|c|c|c|}
\hline \multirow{2}{*}{$\begin{array}{c}\text { Indikator Aspek } \\
\text { Diskusi yang } \\
\text { Dinilai }\end{array}$} & \multicolumn{2}{|c|}{ Keadaan } \\
\hline & Siklus I & Siklus II \\
\hline Penguasaan materi & 79,94 & 86,53 \\
\hline $\begin{array}{l}\text { Penyampaian } \\
\text { materi }\end{array}$ & 79,64 & 131,42 \\
\hline Kerjasama & 80,19 & 87,22 \\
\hline $\begin{array}{l}\text { Kemampuan } \\
\text { menjawab }\end{array}$ & 80,42 & 86,25 \\
\hline $\begin{array}{l}\text { Media yang } \\
\text { digunakan }\end{array}$ & 80,33 & 87,08 \\
\hline Rata-rata & 82,50 & 86,50 \\
\hline
\end{tabular}

Rata-rata peningkatan aktivitas sebesar 4 point dalam hal kemampuan penguasaan materi, penyampaian materi; kerjasama, 
kemampuan menjawab pertanyaan dan penggunaan media.

4). Selain pengamatan terhadap aktivitas peserta didik dilakukan pengamatan aktivitas guru. Perubahan peningkatan aktivitas guru yang diamati guru IPA teman sejawat melalui lembar observasi diperoleh pada Tabel 4.

\section{Tabel 4. Peningkatan Aktivitas Guru dalam Pembelajaran}

\begin{tabular}{|c|c|c|c|}
\hline \multirow{2}{*}{$\begin{array}{l}\text { Aspek-aspek yang } \\
\text { diminati }\end{array}$} & \multirow[t]{2}{*}{ Rincian aktivitas guru } & \multicolumn{2}{|c|}{ Penilaian } \\
\hline & & Siklus I & Siklus II \\
\hline \multirow[t]{2}{*}{ Pendahuluan } & 1. Melakukan pembukaan dalam pembelajaran & Cukup baik & Sangat baik \\
\hline & $\begin{array}{l}\text { 2. Memberikan pemotivasian kepada peserta didik } \\
\text { belajar }\end{array}$ & Sangat baik & Sangat Baik \\
\hline \multirow{3}{*}{$\begin{array}{l}\text { Materi dan Media } \\
\text { yang diguna kan }\end{array}$} & 3. Menjelaskan rumusan tujuan pembelajaran & Cukup baik & Cukup baik \\
\hline & 4.Penyampaian materi urutan pembelajaran & Cukup baik & Sangat baik \\
\hline & $\begin{array}{l}\text { 5.Penggunaan media yang digunakan dalam } \\
\text { pembelajaran }\end{array}$ & Sangat baik & Sangat Baik \\
\hline \multirow{5}{*}{$\begin{array}{l}\text { Proses } \\
\text { pembelajaran : } \\
\text { interaksi, peserta } \\
\text { didik, guru dan } \\
\text { pembim bingan }\end{array}$} & $\begin{array}{l}\text { 6. Penggunaan dan pemanfaatan waktu yang tersedia } \\
\text { bagi peserta didik untuk bertanya }\end{array}$ & Cukup baik & Sangat Baik \\
\hline & $\begin{array}{l}\text { 7. Interaksi peserta didik dengan peserta didik dalam } \\
\text { kelompoknya/groupnya }\end{array}$ & Tidak Baik & Sangat Baik \\
\hline & 8. Interaksi guru dengan peserta didik & Cukup baik & Cukup baik \\
\hline & $\begin{array}{l}\text { 9. Kemampuan guru dalam membimbing kerja } \\
\text { kelompok peserta didik }\end{array}$ & Sangat baik & Sangat Baik \\
\hline & $\begin{array}{l}\text { 10. Pembimbingan dalam diskusi dan menutup } \\
\text { pembelajaran }\end{array}$ & Cukup baik & Cukup baik \\
\hline
\end{tabular}

Dari 10 aktivitas guru, 6 di antaranya tetap dan 4 lainnya naik. Artinya pemilihan proses pembelajaran penilaian berbasis kelas dapat menggugah semangat guru dalam meningkatkan aktivitas mengajarnya.

5). Peningkatan keterampilan peserta didik pada Siklus I dengan persilangan monohibrida dan pada Siklus II persilangan dihibrida diperoleh terlihat pada Tabel 5.

\section{Tabel 5. Peningkatan Penilaian Keterampilan Persilangan}

\begin{tabular}{lcc}
\hline \multirow{2}{*}{$\begin{array}{c}\text { Aspek Keterampilan } \\
\text { yang Dinilai }\end{array}$} & \multicolumn{2}{c}{ Keadaan } \\
\cline { 2 - 3 } & Siklus I & Siklus II \\
\hline $\begin{array}{l}\text { Menyiapkan alat } \\
\text { Menutup mata dan }\end{array}$ & 84,44 & 87,78 \\
mengambil kancing & 87,78 & 92,22 \\
genetika & & \\
Memasang kancing & 89,72 & 92,22 \\
genetika & & \\
Menghitung Peluang & 87,22 & 89,44 \\
Rata-rata & $\mathbf{8 8 , 1 1}$ & $\mathbf{9 1 , 2 2}$ \\
\hline
\end{tabular}

Rata-rata aspek keterampilan meningkat sebesar 3,11 point dalam hal menyiapkan alat praktek, keterampilan menutup mata dan mengambil kancing genetika, keterampilan memasang kancing genetika, dan keterampilan menghitung peluang.

6). Perubahan akhir pembelajaran masingmasing siklus adalah tes hasil belajar menggunakan soal pilihan ganda yang diperoleh, terlihat pada Tabel 6 .

Tabel 6. Perbandingan Hasil Belajar Peserta Didik

\begin{tabular}{lcc}
\hline \multirow{2}{*}{ Keterangan } & \multicolumn{2}{c}{ Hasil Belajar } \\
\cline { 2 - 3 } & Siklus I & Siklus II \\
\hline KKM & 80 & 80 \\
Daya Serap & 80,83 & 86.11 \\
Nilai Maksimal & 100 & 100 \\
Nilai Minimal & 70 & 70 \\
$\begin{array}{l}\text { Peserta didik yang } \\
\text { Tuntas }\end{array}$ & 27 & 34 \\
$\begin{array}{l}\text { Peserta didik yang } \\
\text { belum Tuntas }\end{array}$ & 9 & 2 \\
$\begin{array}{l}\text { Prosentase peserta } \\
\text { didik Tuntas }\end{array}$ & $75.00 \%$ & $94,44 \%$ \\
$\begin{array}{l}\text { Prosentase peserta } \\
\text { didik Tidak Tuntas }\end{array}$ & $25.00 \%$ & $5.56 \%$ \\
\hline
\end{tabular}


Kriteria Ketuntasan Minimal $(\mathrm{KKM}=80)$ sebagai standar pencapaian hasil belajar dapat dijelaskan pada Siklus I dibandingkan dengan Siklus II, daya serap meningkat sebesar 5,28 point, peserta didik yang tuntas KKM meningkat sebanyak 7 orang $(19,44 \%)$.

Penilaian kelas merupakan suatu proses yang dilakukan melalui langkah-langkah perencanaan, penyusunan alat penilaian, pengumpulan informasi melalui sejumlah bukti yang menunjukkan pencapaian hasil belajar peserta didik, pengolahan, dan penggunaan informasi tentang hasil belajar peserta didik. Penilaian kelas dilaksanakan melalui berbagai cara, seperti penilaian unjuk kerja (performance), penilaian sikap, penilaian tertulis (paper and pencil test), penilaian proyek, penilaian produk, penilaian melalui kumpulan hasil kerja/karya peserta didik (portofolio), dan penilaian diri [16]. Hal ini senada dengan hasil penelitian yang memberikan penilaian terhadap hasil belajar siswa tidak hanya sebatas pada evaluasi ulangan, akan tetapi secara menyeluruh dengan berbagai perbandingan penilaian. Penelitian tindakan kelas ini untuk mengungkap efektivitas dari pembelajaran dengan mengunakan penilaian berbasis kelas ini digunakan sebagai upaya untuk memperbaiki kualitas pembelajaran yang dilakukan oleh guru di kelas, sehingga dapat memberikan semangat dan motivasi tinggi bagi siswa untuk belajar hal ini terlihar dari kegiatan pembelajaran yang dilakukan tiap siklusnya meningkat keikutsertaan siswa dan keaktifannya dalam kegiatan pembelajaran berlangsung.

Guru diharapkan mampu untuk menerapkan bagaimana proses pembelajaran dengan menggunakan penilaian berbasis kelas. Hasil penelitian menunjukkan bahwa model pelatihan yang efektif meningkatkan kemampuan guru dalam menyusun perangkat penilaian [17].
Berdasarkan pendapat tersebut memperlihatkan bahwa dalam kegiatan pembelajaran yang telah dilakukan hendaknya guru telah terlebih dahulu menguasai teknik penyusunan perangkat penilai berbasis kelas dalam menunjang kegiatan penelitian tindakan kelas yang dilakukan. Diharapkan dengan penelitian tindakan kelas ini dapat memperbaiki proses kegiatan pembelajaran. Dengan perbaikan proses maka akan berimbas pada peningkatan hasil belajar siswa. Pembelajaran dengan menggunakan penilain berbasis kelas pada materi persilangan terbuktif efektif meningkatakn prestasi belajar siswa yang dilihat dari nilai hasil belajar dan sikap siswa ketika mengikuti kegiatan pembelajarn di kelas.

\section{SIMPULAN}

Hasil pelaksanaan penelitian tindakan kelas dengan pembahasan dapat disimpulkan bahwa melalui metode penilaian berbasis kelas dapat peningkatan prestasi belajar peserta didik pada materi persilangan (pengetahuan dan keterampilan) dengan rincian bahwa terdapat; 1). Peningkatan aktivitas peserta didik yang relevan; 2). Peningkatan aktivitas KBM peserta didik dengan LKPD; 3). Peningkatan aktivitas diskusi peserta didik; 4). Peningkatan nilai keterampilan peserta didik; 5). Peningkatan hasil belajar; dan 6). Peningkatan aktivitas guru.

\section{DAFTAR PUSTAKA}

[1] E. Parmin, \& Peniati, "Pengembangan modul mata kuliah strategi belajar mengajar ipa berbasis hasil penelitian pembelajaran," $J$. Pendidik. IPA Indones., vol. 1, no. 1, pp. 8-15, 2012.

[2] N. W. Juniati dan I. W. Widiana, "Penerapan Model Pembelajaran Inkuiri Untuk Meningkatkan Hasil Belajar IPA," J. Educ. Action Res., vol. 1, no. 2, pp. 122-132, 2017, doi: 
10.23887/jear.v1i2.12045.

[3] Roestiyah, Masalah Pengajaran. Jakarta: Bina Aksara, 1986.

[4] M. Natalina, E. Suryawati, dan S. Rukmana, "Pengembangan Perangkat Penilaian Berbasis Kelas pada Mata Pelajaran Biologi SMA Kelas XI," J. Biog., vol. 11, no. 2, pp. 111-118, 2015.

[5] T. Hilaliyah, "Penilaian Berbasis Kelas," J. Membaca (Bahasa dan Sastra Indones., vol. 3, no. 1, p. 73, 2018 , doi: 10.30870/jmbsi.v3i1.3747.

[6] N. . Gronlund, Assessmen of Student Achievement. Needhan Heights, MA: Aviacom Company, 1998.

[7] B. Tola, "Managemen Peningkatan Mutu Pendidikan,” Makalah, 2004.

[8] G. Sinuraya, "Jurnal Pendidikan Ilmu Sosial Media Komunikasi antara Fakultas," J. Pendidik. Ilmu Sos. Media Komun. antara Fak.

[9] A. Sardiman, Interaksi dan Motivasi Belajar Mengajar. Jakarta: Raja Grafindo Persada, 2000.

[10] S. Arikunto, Dasar-dasar Evaluasi Pendidikan. Jakarta: Bumi Aksara, 1993.

[11] N. Sudjana, Prestasi BelajarMengajar. Bandung: Sinar Baru Algensindo, 1998.

[12] S. B. D. dan A. Zain, Strategi Belajar Mengajar. Jakarta: Rineka Cipta, 2006.

[13] N. N. Metaputri, N. K., Margunayasa, I. G., \& Garminah, "Pengaruh Model Pembelajaran Inkuiri Terbimbing Berbasis Lingkungan terhadap Keterampilan Proses," J. PGSD Univ. Pendidik. Ganesha, vol. 4, no. 1, pp. 1-10, 2016.

[14] Wahjosumidjo, "Jurnal Orasi Bisnis Edisi ke-IX," J. Orasi Bisnis Ed. keIX, 2013.

[15] H. Hurriyati, "Peningkatkan Aktivitas Siswa Menggunakan
Media Papan Catur tentang Materi Pewarisan Sifat Kelas IX SMPN 4 Kota Solok," J. Eksakta Pendidik., vol. 4, no. 1, pp. 105-113, 2020, doi: 10.24036/jep/vol4-iss1/399.

[16] H. Baharun, "Penilaian Berbasis Kelas Pada Pembelajaran Pendidikan Agama Islam di Madrasah," Model. J. Progr. Stud. PGMI, vol. 3, no. 2, pp. 205-216, 2016.

[17] H. Suwono, "Model Pelatihan Berbasis Kelompok Kerja Guru untuk Meningkatkan Kemampuan Menyusun Perangkat Penilaian Berbasis Kelas," J. Ilmu Pendidik., vol. 16, no. 1, pp. 28-39, 2009. 